\title{
Perbedaan Pengaruh Metode Latihan Plyometric Depth Jump dan Hurdle Hopping Terhadap Peningkatan Power Otot Tungkai Pada Pesilat Remaja Putri Perguruan Tapak Suci Putera Muhammadiyah Simo Boyolali Tahun 2018
}

\author{
Eko Sudarmanto $^{a}$, Agung Pipit Supriyadi ${ }^{b}$, M Idzhar Hakiki ${ }^{c}$ \\ ${ }^{a, b, c}$ Pendidikan Olahraga, Universitas Muhammadiyah Surakarta, Sukoharjo, Central Java 57162, Indonesia
}

*Corresponding author: 1 es348@ums.ac.id, 2agungppt97@ums.ac.id, ${ }^{3}$ idzharhakiki@ums.ac.id

\section{ARTICLE INFO}

Article history:

Received 26 September 2018

Received in revised form 18

October 2018

Accepted 14 November 2018

\section{Keywords:}

Plyometric Exercise Method, Dept. Jump, Hardle hoping, Leg muscles

\begin{abstract}
A B S T R A C T
Based on the problems that have been formulated in this study the aim is to determine the differences in the effect of Hurdle hopping and Depth Jump training on leg muscle power on Adolescent Female Female Student of Tapak Suci College Putera Muhammadiyah Simo Boyolali in 2018 and which exercises have better influence between Hurdle hopping training and Depth Jump on increasing leg muscle strength in the Young Women College of Tapak Suci, Putera Muhammadiyah Simo Boyolali in 2018. The research method used was experimental. Based on the results of the research, the following conclusions can be obtained: There are differences in influence between Depth Jump training and the Hurdle Hopping exercise on the increase in Leg Muscle Power in Adolescent Female Female Fighters in the Tapak Suci College of Putera Muhammadiyah Simo Boyolali in 2014, with $\mathrm{t}$ count $=$ 5.3508 $>\mathrm{t}$ table $=2.093$. Depth Jump training has a better effect than the Hurdle Hopping exercise in mening said the Power of Leg Muscle in Young Women Pesilat in the Tapak Suci College of Putera Muhammadiyah Simo Boyolali in 2014, with an increase in Depth Jump training $=6.239 \%>$ Hurdle Hopping training $=4.278 \%$. In this study, it turned out that Depth Jump training and Hurdle Hopping training both increased power Leg muscles with a significant increase. From this study it can be seen that in groups that use Depth Jumps training or in groups that use Hurdle Hopping exercises both have been shown to increase leg muscle power. From this study it can be seen that in groups using Depth Jumps and group exercises. those using Hurdle Hopping training were both proven to increase leg muscle power. In this study, it turned out that Depth Jump training and Hurdle Hopping exercises were both able to increase leg muscle power with a significant increase.
\end{abstract}

\section{Pendahuluan}

Penulis tertarik dengan masalah power otot tungkai pada pesilat golongan pelajar putri, karena dari observasi yang dilakukan di Perguruan Tapak Suci Putera Muhammadiyah Simo Boyolali banyak Pesilat Remaja Putri yang masih lemah terhadap power otot tungkainya, selain kurang efektifnya bentuk-bentuk latihan yang diterapkan oleh pelatih Perguruan Tapak Suci Putera Muhammadiyah Simo Boyolali, alat-alat yang dimiliki belum begitu memadai khususnya alat-alat yang digunakan untuk latihan peningkatan power otot tungkai. Dari keadaan ini dengan peralatan yang sederhana dan tidak memerlukan peralatan yang mahal untuk mendapatkannya, dan mudah diterapkan di setiap cabang latihan Tapak Suci di Simo Boyolali yaitu dengan metode Hurdle hoping dan Depth Jump, di mana metode Hurdle hoping bisa dilaksanakan atau diterapkan dengan bantuan kursi duduk siswa yang terbuat dari kayu, sedangkan metode depth 
jump bisa dilaksanakan dengan bantuan meja belajar siswa yang terbuat dari kayu. Dari kedua metode latihan ini dirasa sangat cocok untuk diterapkan di Perguruan Tapak Suci Putera Muhammadiyah Simo Boyolali yang hampir semua cabang latihannya berkembang di Sekolahan baik negeri ataupun swasta, dengan keadaan yang seperti ini peralatan-peralatan yang dibutuhkan untuk latihan Hurdle hoping dan Depth Jump telah tersedia.

Peluang atlet putri lebih besar apabila mempunyai otot power otot tungkai yang sempurna. dan tidak memerlukan peralatan yang mahal untuk mendapatkannya, dan mudah diterapkan di setiap cabang latihan Tapak Suci di Simo Boyolali yaitu dengan metode Hurdle hoping dan Depth Jump, di mana metode Hurdle hoping bisa dilaksanakan atau diterapkan dengan bantuan kursi duduk siswa yang terbuat dari kayu, sedangkan metode depth jump bisa dilaksanakan dengan bantuan meja belajar siswa yang terbuat dari kayu. Dari kedua metode latihan ini dirasa sangat cocok untuk diterapkan di Perguruan Tapak Suci Putera Muhammadiyah Simo Boyolali yang hampir semua cabang latihannya berkembang di Sekolahan baik negeri ataupun swasta, dengan keadaan yang seperti ini peralatanperalatan yang dibutuhkan untuk latihan Hurdle hoping dan Depth Jump telah tersedia. Peluang atlet putri lebih besar apabila mempunyai otot power otot tungkai yang sempurna.

\section{Tujuan Penelitian}

Berdasarkan dengan berbagai masalah yang muncul maka peneliti mengambil beberapa masalah yang telah dirumuskan di atas, dengan tujuan penelitian ini untuk mengetahui:

1. Adakah perbed aan pengaruh latihan hurdle hoping dan dalam penelitian ini mempunyai tujuan untuk mengetahui apakah latihan depth jump ada pengaruhnya terhadap peningkatan power otot tungkai pada pesilat remaja putri perguruan tapak suci putera
Muhammadiyah Simo Boyolali tahun 2018 ?

2. Manakah latihan yang lebih baik Penngaruhnya antara hurdle hoping dan depth jump terhadap peningkatan power otot tungkai pada pesilat remaj a putri Simo Boyolali tahun 2018 ?

\section{Tinjauan Pustaka}

\section{a. Pengertian power}

Power atau daya ledak di sebut juga sebagai kekuatan eksplosif power. Power mempunyai beberapa elemen yang menyangkut kekuatan dan kecepatan kontraksi otot yang sangat dinamis dan eksplosif serta melibatkan pengeluaraan untuk untuk kekuataan yang maksimal dalam waktu yang secepat cepatnya. Hampir cabang olahraga membutuhkan, Power biasanya mengacu kepada kemampuaan seseorang dalam sewaktu sependek pendeknya. Berkaitan dengan power, Harsono (1988:200) menyatakan power adalah kemampuan otot untuk menggerakkan kekuataan maksimal ,dalam waktu yang sangat cepat".

\section{b. Latihan untuk Meningkatkan Power}

Power merupakan kualitas yang memungkinkan otot untuk menghasilkan kerja fisik secara eksplosif. Penentuan power adalah intensitas kontraksi otot. Intensitas koreksi yang tinggi merupakan kecepatan pengerutan setelah mendapat rangsangan dari syaraf.

Intensitas ini tergantung kontraksi ini tergantung pada rekrutmen sebanyak mungkin jumlah otot yang bekerja kecuali itu produksi kerja otot secara eksplosif menambahkan unsur baru yakni terciptanya hubungan antara otot dengan sistem syaraf. Suharno HP (1993:59-60) menyatakan bahwa faktor yang menentukan baik tidaknya power adalah:

1. Banyaknya sedikit macam fibril otot putih (phasic) dari atlet.

2. Kekuatan dan kecepatan atlit Ingat rumus $\mathrm{p}=\mathrm{fxv}$ P : Power 
F : force

V : velocity

3. Waktu rangsangan maksimal 34 detik misalnya rangsangan hanya 15 detik power akan lebih baik dibandingkan dengan waktu rangsangan selama 34 detik

4. Koordinasi yang harmonisasi antara kekuatan dan kecepatan

5. Tergantung banyak sedikitnya zat kimia dalam otot

6. Penguasaan gerakan dan teknik yang benar

\section{c. Peranan power otot tungkai dalam tendangan pencak silat}

Power otot tungkai merupakan

factor pendukung dalam kemampuan tendangan pada pencak silat. Semakin besar otot tungkai yang dimiliki oleh pesilat maka akan semakin cepat dan kuat hasil tendangan yang dilakukan dengan cepat dan dimiliki oleh pesilat kuat dapat membuat lawan kesulitan dalam menangkis dan menangkap.

\section{d. Anatomi otot tungkai}

Menurut Hadiwidjaya

anatomi anggota gerak bawah

(1996;39) tulang-tulang sebagai berikut :

terdiri
1. femur
2. patella
3. tibia
4. fibula
5. ossa tarsi
6. ossa mata tarsi
7. digiti

\section{1. latihan pliyometrik}

\section{a. Pengertian Pliometrik}

Pengertian pliometrik menurut james dan robert c yang di terjemahkan oleh Furqon $\mathrm{H}$ dan Muchsin Dowes (2000:2) adalah sebagai berikut :

\begin{tabular}{|c|c|c|c|c|}
\hline Kelompok & Tes & $\mathbf{N}$ & Mean & Peningkatan \\
\hline \multirow{2}{*}{$\begin{array}{l}\text { Kelompok } 1 \\
\text { (Depth Jump) }\end{array}$} & Awal & \multirow{4}{*}{20} & 1,7550 & \multirow{2}{*}{0,1095} \\
\hline & Akhir & & 1,8645 & \\
\hline \multirow{2}{*}{$\begin{array}{l}\text { Kelompok2 } \\
\text { (Hurdle } \\
\text { Hopping) }\end{array}$} & Awal & & 1,7295 & \multirow{2}{*}{0,0740} \\
\hline & Akhir & & 1,8035 & \\
\hline
\end{tabular}

Asal istilah plyometric diperkirakan dari bahasa Yunani plythem berarti memperbesar atau meningkatkan dari akar bahasa Yunani plio dan metrich masing-masing lebih banyak dan ukuranya. Pliometrik mengacu pada latihan yang di tandai dengan kontraksi-kontraksi otot yang kuat sebagai respon terhadap pembebanan yang cepat dan sangat dinamis atau adanya peregangan dengan otot- otot yang terlibat.

\section{b. Bentuk-bentuk Latihan}

Dalam latihan daya ledak otot menggunakan latihan pliometrik, ada beberapa macam bentuk latihan yang dapat digunakan ,ini disesuaikan berdasarkan gan daya ledak otot yang akan dilatih. Dalam penelitian latihan yang digunakan adalah untuk melatih daya ledak otot -otot tungkai. Bentuk latihan pliometrik untuk otot tungkai ada berbagai macam ini tergantung dari gerakan yang dilakukan yang dilakukan, dan yang dipergunakan dalam penelitian ini adalah skiping dan jamping yang merupakan latihan nyang $\mathrm{m}$ enekankan pada posisi loncatan untuk mencapai ketinggihan maksimumdan juga jarak horisontal. Skiping dan Jumping dilakukan dengan dua kaki dengan arah medan turun (decline hop) dan dengan arah medan naik (incline bound).

\section{c. Prinsip Latihan Pliometrik}

Dalam latihan olahraga harus selalu mempertahankan prinsip-prisip latihan demikian pula dengan latihan latihgan pliyometrik. Menurut Furqon dan H Muhchin Dowes (2002: 8-9) bahwa "prinsip yang dasar dan banyak di terima adalah prinsip beban lebih yang mendasar dan banyak di terima adalah prinsip bebsn ysng progresif,di samping prinsip dasar yang sepesifikasi yang selama ini sangat berhasil digunakan 
untuk mengembangkan kekuatan, power ,dan daya tahan".

\section{d. Dasar- dasar latihan pliyometrik}

Latihan plyometrik adalah merupakan perwujudan dari daya ledak otot latihan perpaduaan antara kekuatan dan kecepatan yang oleh karena itu pliometrik merupakan metode latihan yang sangat efektif untuk meningkatkan kemampuaan daya ledak otot (eksplosif power).

\section{e. Dosis latihan pliyometric}

Dalam pemberiaan dosis latihan harus direncanakan, penyusunan dan diprogramkan dengan yang baik sehingga dapat mewujudkan tujuan yang di rencanakan dapat tercapai. Dalam pembuatan program latihan, Dangsina Moeloek dan Artjamo Tjokronegoro (1984 : 12-14) menyebutkan, dalam, dalam pembuataan program latihan harus meliputi faktorfaktor sebagai berikut:

1. Tipe latihan

2. Intensitas latihan

3. Frekuwensi latihan

4. lama latihan

\section{2. latihan depth jump}

Latihan plyometric bentuk depth jumps merupakan bentuk latihan yang mempunyai tujuan yang sama yaitu melatih kemampuan power tungkai tapi dalam pelaksanaan bentuk latihan ini menuntut pada tingginya hasil lompatan setelah melakukan lompat dari ketinggian. Analisis gerakan depth jumps menurut Harsono (200: 43) adalah : berdiri atas kotak /bangku lalu melompat ke atas dan ke depan: mendarat dilantai dengan mengeper, lalu dengan serta merta melompat lagi ke atas kotak / bangku ke dua, kemudian dari bok ke dua melompat setinggitingginya dan sejauh-jauhnya kemudian mendarat dengan mengeper".

\section{Latihan Hurdle hopping}

Latihan pliometrik dengan metode hurdle hopping adalah meloncat kedepan dengan pendaratan dua kaki secara cepat dan eksplosif melewati rintangan kotak atau penghalang lain yang ditekankan pada kecepatan gerakan kaki untuk mencapai lompat/loncat setinggi - tingginya dan sejauh - jauhnya kearah depan saja. Menurut Sukadiyanto (2005: 96) bentuk latihan pliyometric di kelompokkan dua macam : latihan dengan intensitas rendah yaitu melompat di atas kotak atau penghalang lain setinggi $25-35 \mathrm{~cm}$ dan latihan denganintensitas tinggi yaitu melompat di atas kotak atau penghalang lain setinggi di atas $35 \mathrm{~cm}$ tergantung kemampuan".

\section{Metode Penelitian}

Metode dalam penelitian ini, selaku peneliti yang digunakan adalah eksperimen. Penelitian eksperimen adalah sebuah kegiataan percobaan yang diawali dengan memberikan perlakuaan kepada subyek yang di akhiridengan sebuah bentuk tes guna mengetahui pengaruh perlakuaan yang telah melakukaandi berikaan. Dalam hal ini Suharsimi Arikunto (1998:9) menyatakan bahwa : eksperimen adalah suatu cara untuk mencari hubungan sebab akibat (hubungan kausal) antara 2 faktor yang sengaja ditimbulkan oleh peneliti dengan mengeliminasi atau mengurangi atau menyisihkan faktor-faktor lain yang bisa mengganggu. Eksperimen selalu dilakukan dengan maksud untuk melihat akibat dari suatu perlakuan.

\section{Hasil}

Pada bab ini disajikan mengenai hasil penelitian beserta interprestasinya. Dalam Penyajian yang kami hasilkan penelitian ini berdasarkan analisis statistik yang dilakukan pada tes awal dan tes akhir setelah dilakukanya tritmen pada peningkatan Power Otot Tungkai Pada Pesilat Remaja Putri Perguruan Tapak Suci Putera Muhammadiyah Simo Boyolali Tahun 2018. Berikut ini peneliti sajikan deskripsi data, uji 
prasyarat analisis, hasil analisis data dan pengujian hipotesis.

\section{A. Deskripsi data}

Deskripsi hasil analisis data hasil tes peningkatan Power Otot Tungkai Pada Pesilat Remaja Putri Perguruan Tapak Suci Putera Muhammadiyah Simo Boyolali Tahun 2014 yang dilakukan pada kelompok I (KI) dan kelompok II (K2) disajikan dalam bentuk tabel sebagai berikut :

Tabel Deskripsi data hasil analisis sebelum mendapat perlakuaan

\begin{tabular}{|l|l|l|}
\hline Tes & Reliabilitas & Kategori \\
\hline Awal & 0,9817 & Acceptable \\
\hline Akhir & 0.9222 & Exelent \\
\hline
\end{tabular}

Gambaran nilai rata-rata tes awal dan akhir pada kelompok 1 dan 2 dibuat histogram perbandingan sebagai berikut :

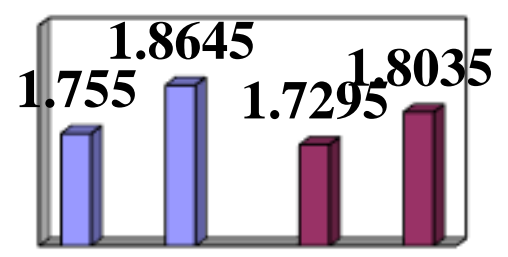

$\square$ Kelompo

$\square$ Kelompo

Gambar 1. Histogram pada Data tes Awal dan data tes Akhir Kelompok 1 dan 2.

Kelompok yang perlakuan dengan latihan Depth Jump dan latihan Hurdle Hopping masing-masing memberikan pengaruh yang berbeda terhadap peningkatan power otot tungkai. Pada kelompok dengan latihan Depth Jump, memiliki peningkatan 0,1095 atau peningkatan $6,239 \%$, sedangkan pada kelompok dengan latihan Hurdle Hopping, memiliki peningkatan 0,0740 atau peningkatan 4,278\%. Peningkatan lebih besar terjadi pada kelompok dengan perlakuan latihan Depth Jump.

\section{B.Pengujian persyarataan pengujiaan}

Sebelum dilakukan analisis data, perlu dilakukan pengujian persyaratan analisis. Pengujian persyaratan analisis yang dilakukan yaitu dengan uji reliabilitas, uji normalitas dan homogenitas.

\section{Uji Reliabilitas}

Untuk mengetahui tingkat keajegan hasil tes peningkatan kecepatan tendangan pada olahraga pencak silat, dilakukan uji reliabilitas. Hasil uji reliabilitas awal dan tes akhir peningkatan Power Otot Tungkai Pada Pesilat Remaja Putri Perguruan Tapak Suci Putera

Dari penjabaaraan tabel di atas diketahui bahwa, nilai reliabilitas dalam tes awal adalah sebesar 0,9817, di mana termasuk dalam kategori acceptable. Ada pun nilai reliabilitas dalam tes hasil akhir adalah sebesar 0,9922 dimana hasil tersebut termasuk dalam kategori excelent. Dalam menjabarkan pengertian koefisien reliabilitas tes tersebut, maka peneliti menggunakan pedoman tabel koefisien reliabilitas tes tersebut. Peneliti menggunakan pedoman tabel koefisiensi strand peneliti menggunakan pedoman tabel koefisien Stendo \& Wilson 1993 dari Mulyono B (2011: 49) sebagai berikut:

\begin{tabular}{|l|l|}
\hline Koefisieen & Reliabilitas \\
\hline $95-99$ & Exelent \\
\hline $90-94$ & Very good \\
\hline $80-89$ & Acceptable \\
\hline $70-79$ & Poor \\
\hline $60-69$ & QuestiOnable \\
\hline
\end{tabular}

\section{Uji Normalitas}

Peneliti sebelum melakukan analisis data perlu diuji didistribusi kenormalanya .Uji normalitas data penelitian ini di gunakan metode liliefors. Hasil dari uji normalitas data yang dilakukan pada tiap kelompok adalah sebagai berikut :

\begin{tabular}{|l|l|l|l|l|l|l|}
\hline $\begin{array}{l}\text { Kelo } \\
\text { mpok }\end{array}$ & N & $\mathbf{M}$ & SD & $\mathbf{L}_{\text {hitung }}$ & $\mathbf{L}_{\text {tabel }}$ & $\begin{array}{l}\text { Kesimp } \\
\text { ulan }\end{array}$ \\
\cline { 1 - 4 } 1 & 2 & $\begin{array}{l}1,75 \\
5\end{array}$ & 1,743 & 0,0175 & & Normal \\
\cline { 1 - 4 } 2 & $\begin{array}{l}2 \\
2\end{array}$ & $\begin{array}{l}1,72 \\
95\end{array}$ & 1,7179 & 0,0160 & 0,190 & Normal \\
\hline
\end{tabular}


Yang dilakukan dari hasil normalitas pada kelompok I $(\mathrm{KI})$ nilai $\mathrm{L}_{\mathrm{O}}=0.175$. Dimana dari hasil tersebut terdapat hasil lebih kecil dari angka diatas penolakan pada taraf signifikan 5\% yaitu 0,190. Dengan demikiaan penelitian dapat disampaikan bahwa data KI termasuk distribusi normal. Dari hasil yang normalitas yang dapat dilakukan pada kelompok II (K2) diperoleh nilai $\mathrm{L}_{\mathrm{O}}=0,0160$. Dimana dari hasil tersebut lebih kecil dari angka, dengan demikiaan batas penolakan pada tarif signifikansi $5 \%$ yaitu 0,190, Dengan demikian dapat disimpulkan dari data yang ada bahwa data K2 juga termasuk berdistribusi normal.

\section{Uji Homogenitas}

Uji homoginitas yang dimaksudkan untuk mengetahui kesakmaan varians dari kedua kelompok. Jika kedua kelompok tersebut memiliki kesamaan varians, maka nantinya kedua kelompok memiliki perbedaan, maka perbedaan tersebut di sebabkan oleh perbedaan rata-rata atau kemampuan.hasil uji homoginitas data antara kelompok I (KI) dan kelompok 2 (K2) sebagai berikut:

\begin{tabular}{|l|l|l|l|}
\hline Tes & $\mathbf{F}_{\text {hitumg }}$ & $\mathbf{F}_{\text {tabel }}$ & Kesimpulan \\
\hline Awal & 1,0472 & 2,04 & Homogen \\
\hline
\end{tabular}

Dari hasil uji homoginitas yang dilakukaan di peroleh nilai fohitung= 1,0472. sedangkan dengan $\mathrm{db}=19$ lawano19, angka $\mathrm{Ft}=2,04$. Ternyata nilai $\mathrm{F}$ hitung= lebihokecil dari Ft. Dikarenakan f hitung < F tabel maka hipotesis nol diterima.

\section{B.Hasil Analisis Data}

Uji perbedaan sebelum dan sesudah diberi perlakuan pada kelompok 1 dan kelompok 2

\begin{tabular}{|c|c|c|c|c|c|}
\hline $\begin{array}{l}\text { kelo } \\
\text { mpo } \\
\text { k }\end{array}$ & $\begin{array}{l}\text { Mea } \\
\text { n }\end{array}$ & Mean & $\mathbf{T}_{\text {hitung }}$ & $\mathbf{t}_{\text {ttabel }}$ & $\begin{array}{l}\text { Kkesimp } \\
\text { ulaan }\end{array}$ \\
\hline 1 & \multirow{2}{*}{$\begin{array}{l}\text { sebel } \\
\text { um }\end{array}$} & 1,7550 & \multirow{2}{*}{1,9029} & \multirow{4}{*}{2.093} & \multirow{2}{*}{$\begin{array}{l}\text { Tidak } \\
\text { Berbeda }\end{array}$} \\
\hline 2 & & 1,7295 & & & \\
\hline 1 & \multirow{2}{*}{$\begin{array}{l}\text { Sesu } \\
\text { dah }\end{array}$} & 1,8645 & \multirow{2}{*}{5,3508} & & \multirow{2}{*}{ Berbeda } \\
\hline 2 & & 1,8035 & & & \\
\hline
\end{tabular}

Dalam penelitian ini dapat dilihat bahwa hasil tes awal tidak terjadi perbedaan yang signifikan antara kelompok satuodengan yang kelompok lain sedangkan hasil tes akhir terjadi perbedaan yang signifikaan antara kelompok 1 dan kelompok. Sedangkan pada hasil tes terakhir, sedangkan pada hasil tes akhir ,terjadi perbedaan yang signifikan antara kelompok 1 dan kelompok

\section{Uji perbedaan tes awal dan tes akhir pada kelompok 1 dan kelompok 2}

Tabel 7 Hasil beda tes awal dan tes akhir kelpmpok satu dengan kelompok 2

\begin{tabular}{|l|l|l|l|l|l|}
\hline $\begin{array}{l}\text { Kelom } \\
\text { pok }\end{array}$ & Tes & Mean & $\mathbf{t}_{\text {hitung }}$ & $\mathbf{t}_{\text {tabel }}$ & $\begin{array}{l}\text { Kesimpu } \\
\text { lan }\end{array}$ \\
\hline \multirow{2}{*}{1} & Awal & 1,7550 & 16,34 & & Berbeda \\
\cline { 2 - 3 } & Akhir & 1,8645 & 32 & \multirow{2}{*}{2.093} & \\
\cline { 2 - 3 } 2 & Awal & 1,7295 & 23,19 & & Berbeda \\
\cline { 2 - 3 } & Akhir & 1,8035 & 74 & & \\
\hline
\end{tabular}

Dalam sajian data terjadi peningkatan yang signifikan, dan kelompok 2 juga terjadi peningkatan yang signifikan ,dan kelompok 2 juga terjadi peningkatan yang signifikan,dan pada kelompok 2 juga terjadi peningkatan yang signifikan , Dengan pembahasan tabel diatas adapun perbesaan lebih besar terjadi pada kelompok kelompok 2 juga terjadi peningkatan yang signifikan. Dengan pembahasan tabel di atas Adapun nilai perbedaan lebih besar terjadi pada kelompok 2.

\section{Uji perbedaan persentase peningkatan}

Pada uji perbedaanodilakukan penghitunganopada masing - masing kelompok untuk mengetahui kebesaran persentase peningkatan pada kelompok 1 dan kelompok 2 berikut adalah penyajian pada tabelnya

Tabel 8. Hasil uji perbedaan persentase peningkatan

\begin{tabular}{|l|l|l|l|l|}
\hline $\begin{array}{l}\text { kelo } \\
\text { mpo } \\
\text { k }\end{array}$ & $\begin{array}{l}\text { Meean } \\
\text { awal }\end{array}$ & $\begin{array}{l}\text { Mean } \\
\text { akhir }\end{array}$ & peningkatan & Persentase \\
\hline 1 & 1,7550 & 1,8645 & 0,1095 & $6,239 \%$ \\
\hline 2 & 1,7295 & 1,8035 & 0,0740 & $4,278 \%$ \\
\hline
\end{tabular}

Dari data di atas bahwa $\mathrm{K} 1$ memiliki peningkatan power otot tungkai dapat diketahui dalam olahraga pencak silat sebesar $6,239 \%$. S edangkan K2 memiliki kemampuaan otot tungkai pada olahraga pencak silat sebesar $4,278 \%$. Dengan hasil 
pembahasaan data di atas demikian dapat disimpulkan bahwa K1 memiliki persentase peningkatan kemampuaan power otot tungkai pada olahraga pencak silat lebih besar dari pada K2

\section{PEMBAHASAN}

\section{Hipotesis I}

Dari pengolahan data yang dalam pembahasan yang ada pada hipotesis 1 yang di peroleh dari data pembahasan tersebut yang didapat sebelum diperlakukan, Kemudiaan setelah dianalisis diperoleh nilai $\mathrm{t}$ antara tes awal pada kelompok 1 dan tes awal kelompok $2=1,9029$, sedangkan $t$ tabel $=2,093$ berarti dari dalam uji hipotesis tersebut tidak terdapat perbedaan yang sangat signifikan. Dengan demikian dengan hasil pemaparan di atas kelompok I dan kelompok II Dengan demikian dari hasil pemaparan di atas kelompok I dan kelompok II berangkat dari titik tolak yang sama,yang berarti apabila setelah di perlakukan dalam keadaan seimbang. Antara kelompok I dan Kelompok II yang berarti apabila setelah diberi perlakuan terdapat perbedaan ,hal itu terjadi karena adanya perbedaan perlakuaan yang diberikan.

Nilai $t$ antara tes awal dan tes akhir pada kelompok $\mathrm{I}=16,3432$ sedangkan totabel $=$ 2.093, berarti hipotesis nol ditolak, dengan demikian dari hasil pembahasaan tersebut dapat disimpulkan bahwa terdapat perbedaan yang signifikan antara hasil tes awal dan tes akhir pada kelompok I . Nilai t antara tes awal dan tes akhir pada kelompok II = 23,1974, maka t tabel $=2.093$, berarti hipotesis nol ditolak , maka dengan demikiaan dari hasil penjelasan dari data di atas dapat disimpulkan bahwa terdapat perbedaan yang signifikan antara hasil tes awal dan tes akhir pada kelompok II.

Dari hasi uji perbedaan yang dilakukaan terhadap hasil tes akhir pada kelompok I dan kelompok II, di peroleh nilai $\mathrm{t}$ hitung $=$ 5,3508 sedangkan $t$ tabel 2,093.Berarti dari hasil analisa hipotesis nol ditolak, dengan hasil demikian maka dapat disimpulkan bahwa dalam penelitiaan tersebut setelah diberikan perlakuan yang berbeda,hasil tes akhir pada kelompok I dan kelompok II. Dikarenakan sebelum di beri perlakukan kedua kelompok berangkat dari titik tolak yang sama, maka dapat disimpulkan bahwa perbedaan signifikan yang terjadi pada hasil tes tes akhir,di sebab kan oleh pemberiaan perlakuaan yang berbeda. Dengan demikian, hipotesis yang menyatakan "Ada perbedaan pengaruh antara latihan Depth Jumps dan latihan Hurdle Hopping terhadap peningkatan Power Otot Tungkai Pada Pesilat Remaja Putri Perguruan Tapak Suci Putera Muhammadiyah Simo Boyolali Tahun 2018" dapat diterima.

\section{Hipotesis II}

Kelompok I yang diberikan perlakuan latihan dengan Depth Jump memiliki peningkatan sebesar 0,1095 atau mengalami peningkatan 6,239\%.Sedangkan pada kelompok II melihat hasil hitung yang di berikan pada kelompok yang di beri perlakuaan dengan hardle hoping memiliki peningkatan sebesar 0,0740oatau mengalami peningkatan $4,278 \%$. Dengan demikian hipotesis yang menyatakan bahwa "latihan latihan Hurdle Hopping tidak lebih baik dibandingkan dengan latihan Depth Jump dalam meningkatkan Power Otot Tungkai Pada Pesilat Remaja Putri Perguruan Tapak Suci Putera Muhammadiyah Simo Boyolali Tahun 2018" dapat diterima.

Dalam hal ini dikarenakan setiap latihan tentu memiliki pengaruh yang berbeda-beda terhadap tujuan yang diinginkan. Latihan dengan menggunakan latihan metode depth jump merupakan salah satu latihan kombinasi untuk meningkatkan power otot tungkai dengan di awali turun dari sebuah bangku, dilanjut melakukan loncatan setinggi-tingginya. Depth Jump sangat baik untuk otot-otot quadricept dan hipogirdle, dan juga untuk punggung bagian bawah serta hamstrings serta dapat diterapkan untuk berbagai cabang olahraga karena menggunakan kekuatan dan kecepatan tungkai. Dengan hal tersebut, maka dapat meningkat kemampuan power otot tungkai pesilat. 


Latihan dengan Hurdle $\begin{array}{r}\text { Hopping } \\ \text { dengan }\end{array}$
merupakan meloncat kedepan kecara cepat dan
pendaratan dua kaki secan
eksplosif melewati rintangan kotak atau
penghalang lain yang ditekankan pada
kecepatan gerakan kaki untuk mencapai
lompat/loncat setinggi-tingginya dan sejauh-
jauhnya kearah depan saja. Hurdle hopping
bisa dianggap sebagai aktivitas aerobic
karena memerlukan kontraksi berirama dari
kelompok-kelompok otot besar dari tungkai
untuk memindahkan seluruh berat badan.
Latihan ini dapat meningkatkan otot gulteals,
gastrochemins, guadricept, hamstrings,
fuksor pinggul, otot-otot punggung bagian
bawah, dan perut.

\section{Simpulan dan Rekomendasi}

\section{A. Simpulan}

Berdasarkan hasil penelitian yang telah dilakukan, dapat diperoleh simpulan sebagai berikut:

1. Ada perbedaan pengaruh antara metode latihan depth jump dan latihan hardlehoping terhadap peningkatan po wer otottungkai pada pesilat remaja putri perguruaan tapak suci putera Muhammadiyah Simo Tahun 2014, d engan terhitung $=5,3508>\mathrm{t}$ tabel $=$ 2,093 .

2. Latihan Depth Jump memiliki pengaruh yang lebih baik dari pada latihan $\mathrm{Hu}$ rdlehopping dalam meningkatkan Po wer Otot tungkai pada Pesilat Remaja Putri Perguruan Tapak Suci Puteri Muhammadiyah Simo Boyolali Tahun 2014, dengan peningkatan latihan Depth Jump $=6,239 \%>$ latihan Hurdle Hopping $=4,278 \%$.

\section{B. Implikasi}

Dari hasil penelitian ini dapat dik etahui bahwa pada kelompok yang meng gunakan latihan Depth Jumps maupun pa da kelompok yang menggunakan latihan Hurdle Hopping keduanya terbukti dapat meningkatkan power otot tungkai. Besarnya peningkatan dari hasil penelitian masing masing metode latihan tersebut juga berbeda-beda dan sama sama signifikan, hal ini dipengaruhi oleh berbagai karakteristik dalam latihan yang diberikan. Dalam setiap karakteristik latihan yang berbeda menimbulkan berbagai efek pada tubuh yang berbeda menimbulkan berbagai efek pada tubuh yang berbeda, sehingga terjadilah perbedaan hasil yang singnifikan .setiap jenis latihan memiliki tipe kerjaya ng berbedsa, perbedaan tipe kerja inilah yang berpengaruh terhadap power otot tungkai.

Dari implikasi yang diberikan bah wa power otot tungkai dapat meningkat melalui latihan yang diberikan,obaik men ggunakan latihan depth jump maupun me nggunakan latihan hardle hoping . Dalam latihan untuk meningkatka otot power tungkai ,pesilat atau pelatih memilih ssuatu metode latihan untuk meningkatkan power otot tungkai yang sesuai, dengan setrategi latihan teknik dengan setrategi latihan teknik dasar yang bertujuaan agar pemain dapat menampilkan gerakian yang tepat dan sempurna. Untuk mengatahui peningkatan keefektifan maka perlu latihan yang mana, yang lebih baik pengaruhnya terhadap peningkatan yang signifikan dalam peningkatan power otot tungkai,dilihat yang dilakukan maka akan muncul adaptasi tubuh saat gerakan yang menerima latihan tersebut, atau seorang pelatih akan menyesuaikan dengan kondisi pesilat. Sehingga dalam penelitiaan ini, ternyata latihan depth jump maupun latihan depth jump maupun latihan hurdle hoping keduanya mampu meningkatkan power otot tungkai dengan peningkatan dengan peningkatan ynag signifikan.

\section{Saran}

Berhubungan dengan hasil penelitiaan ini maka dapat simpulan yang telah diambil dan yang timbulkan, maka kepada para pesilat, pelatih dan kekususa nya peneliti selanjutnya, Disarankan halhal sebagai berikut :

1. Seorang pelatih dalam memilih jenis latihan, khususnya latihan yang digun 
akan untuk meningkatkan power otot tungkai,hendaknya memilih latihan yang lebih baik secara teori dari hasil penelitiaan ini untuk meningkatkan power otot tungkai.

2. Dalam upaya untuk meningkatkan power otot tungkai, pelatih dapat menggunakan berbagai latihan, dianta ranya latihan depth jump maupun latihan hurdle hoping yang mana dalam penelitian ini keduanya terbukti dapat meningkatkan power otot tungkai, walaupun latihan depth jump lebih baik pengaruhnya dari pada latihan hurdle hopping

\section{Daftar Pustaka}

A.Hadiamsyah Noer.1996.Ilmu Kepelatihan Lanjut. Surakarta : UNS pres

Andi Suhendro. 1999.Dasar-asar kepelatihan. Jakarta Universitas Terbuka

Bompa, TO. 1994. Power Training for Sport. Antario: Coaching Association of Canada.

Harsono. 1988. Aspek-aspek psikologis dalam coaching. Jakarta : Depdikbud : Dirjendikti

Joko Subroto dan Moch Rohadi . 1994. Kaidah-Kaidah Pencak Silat. Solo : C. V. Aneka

Lubis, J.(2005). Panduan Praktis Pencak Silat. Jakarta : Rajawali

Moelek, D. dan Tjokronagara, A. 1984. kesehatan dan olahraga. Jakarta: Fakultas Kedokteran Universitas Indonesia

Mulyono B.A. 1990. Pembinaan Prize dan Peningkatan Kondisi Fisik. Surakarta: FKIP UNS.

Munas XII IPSI. 2007. Peraturan Pertandingan Pencak Silat IPSI.
Jakarta: PB IPSI.

Nosseck, J. 1982.General Theory of Training.Logos: Pan African Pres

Nosesect, josep. 1995. General Theory Of Training (M.Furqon Terjemahan) Logos:Pan African Prees

Rusli Lutan dkk. 1992. Manusia dan Olahraga. Bandung: IKIP FPOK. Bandung.

Sadoso Sumosardjuno. 1994. Pengetahua $n$ Praktis Kesehatan Dalam Olahraga. Jakarta: PT. Gramedia.

Sajoto, M. (1995). Pembinaan Kondisi Fisik Dalam Olahraga.semarang:Dahara

Sarwoto \& Bambang Soetedjo. 1993. PendidikanKesehatan dan P3P. Depdikbud: Direktorat Jendral pen didikan dasar dan menengah. Direktorat pendidikan guru dan tenaga teknis bagian proyek penataran guru pendidikan jasmani dan kesehatan SD setara D-II.

Satimin Hadiwidjaya, 1996. Anatomi II. Surakarta: Universitas Sebelas Maret Press.

Suharno HP. 1993. Metodologi Penelitian. Yogyakarta: IKIP Yogyakarta.

Suharsimi, Arikunto.1985. Prosedur Penelitian Suatu Pendekatan Praktek. : Yogyakarta : Rineka Cipta

Sukadiyanto.2002. Pengantar Teori dan Metodologi Melatih Fisik. Yogyakarta FIK UNY

Soekarman, R. 1991. Energi dan Sistem Energi Predominan Pada Olahraga. Jakarta 
